\title{
POLLEN TUBE AND SPERMATOGENESIS IN IRIS
}

CONTRIBUTIONS FROM THE HULL BOTANICAL LABORATORY 235

M. LouISE SAWYER

\section{(WITH EIGHTEEN FIGURES)}

This study of spermatogenesis had its origin in an attempt to find a satisfactory method of securing prepared as well as living material for demonstrating pollen tubes to a class in embryology. The fact that it was found possible to dissect out the pollen tubes of Iris versicolor, so that tubes of various lengths, developed on the stigma and style, became available for study, made it seem advisable to undertake an investigation of the pollen tube of this species. Tubes were also secured in longitudinal sections of style and stigma, and by sowing pollen grains on culture media. Tubes were grown in sugar solutions, the $15-30$ per cent proving more satisfactory than weaker solutions. A culture medium was made by adding 30 per cent sugar solution to the sap which oozes from freshly cut stalks, and abundantly from the clasping bases of the leaves. The superiority of the latter over the pure sugar solution lies in the fact that as the tubes grow longer they are less likely, in the cell sap sugar solution, to become distorted. Its disadvantage consists in the difficulty of freeing the tubes from the gelatinous medium.

Flemming's stronger solution proved the most satisfactory killing fluid, and iron-hematoxylin has been the favorite stain. The successful dissection of the tubes is related to the structure of the style. That organ arises from the ovary as a single structure, and at the height of about $\mathrm{I} \mathrm{cm}$. divides into 3 branches. Cross-sections of a stylar branch (fig. I) reveal the fact that each branch is traversed by a longitudinal groove. When the flower is mature, the stylar groove is covered by two overlapping outgrowths, arising from the margin of the groove and so forming an inclosed canal, diagrammatically shown in fig. 2. Near the distal end the groove broadens out and terminates in the stigma, which appears as a shelflike projection from the under side of the stylar branch, which 


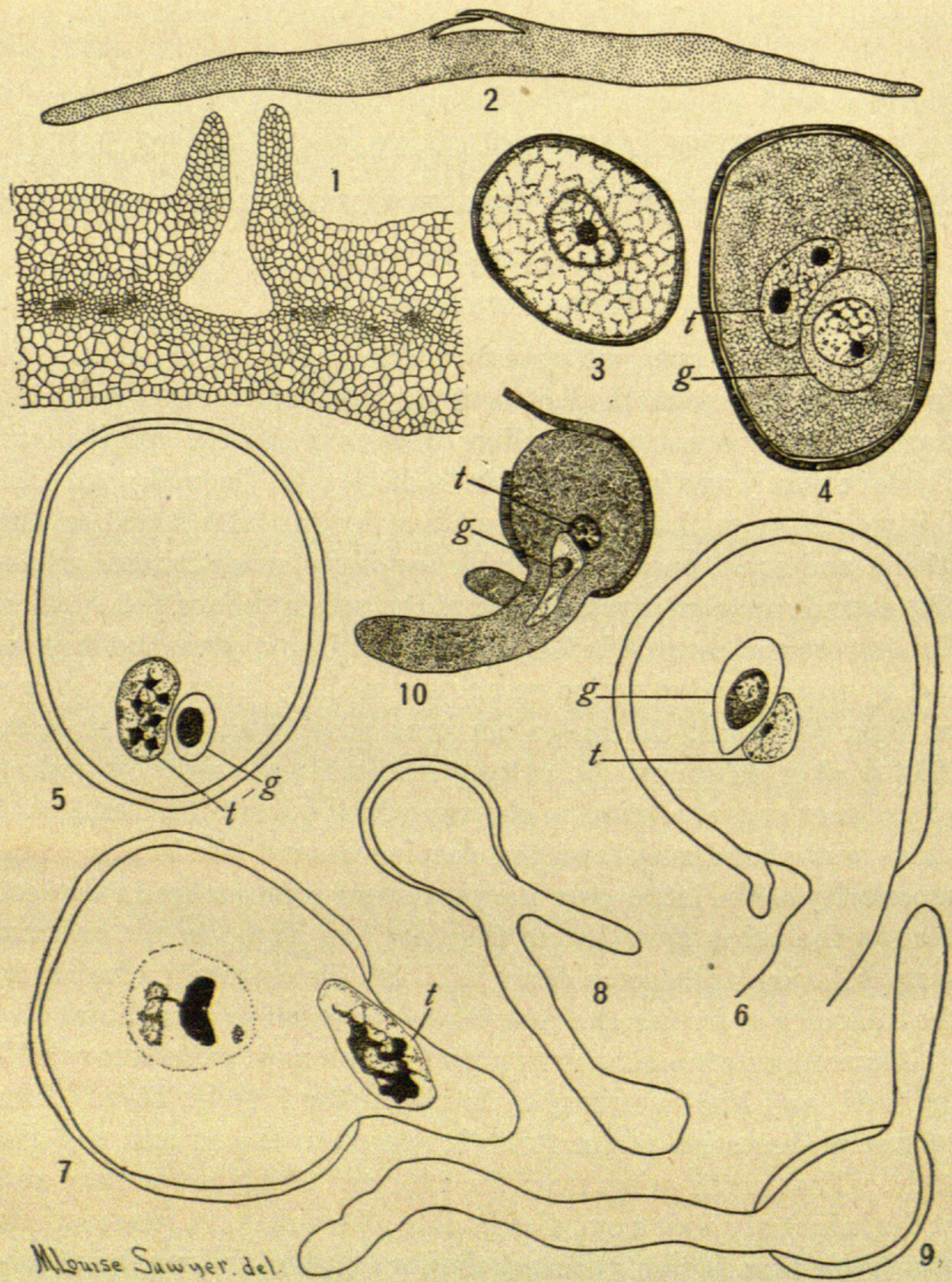

FiGs. I-10.-Abbreviations are as follows: $t$, tube nucleus; $g$, generative cell; $m$, male cell; $e$, egg; fig. $\mathrm{I}$, transverse section of young stylar branch, showing groove through which pollen tubes grow, $X_{124}$; fig. 2, diagram of mature stylar branch, in transverse section, showing groove covered; fig. 3 , young pollen grain, $\mathrm{XIII}_{3} ;$ fig. 4 , mature pollen grain from section of anther, XIII 3 ; fig. 5, pollen grain sectioned on stigma, showing end view of tube nucleus and generative cell, $X \mathrm{IrI}_{3}$; fig. 6 , pollen grain and tube grown on stigma, tube nucleus and generative cell being still within the grain, $\times \mathrm{III}_{3}$; fig. 7, pollen grain with short tube into which tube nucleus is passing; generative cell poorly defined, still in center of grain, $\mathrm{XIII}_{3}$; fig. 8, pollen tube grown in sugar solution, showing branching tube, $X_{540}$; fig. 9 , pollen tube grown in sugar solution, showing 2 tubes from a single grain, $\times 540 ;$ fig. 1o, pollen grain $(p g)$ of fig. $\mathrm{Ir}$, showing generative cell in act of entering tube, tube nucleus following, $\times 540$. 
is continued beyond the stigma. By removing the covers of the groove the canal containing the tubes lies exposed, and they can be removed with needles.

Tubes grown in hanging drops of culture media show a rather striking tendency to grow from the margins of the drop in groups, the tubes being in close contact with each other. This fact is suggestive when associated with the fact that from the stigma the pollen tubes converge in two lines and traverse the stylar branch at the margins of the groove, where the space is most restricted (fig. 2). It has usually been assumed that the pollen tube is guided in its direction of growth by chemotaxis. These observations suggest that in Iris contact stimulus may be an effective guide. Further investigation of this point is purposed.

The structure of the newly formed pollen grain (fig. 3) was studied in sections of the anther. The division of the microspore nucleus was not observed, but it occurs in the anther, as would be expected, and the generative cell is organized before dehiscence (fig. 4). The generative cell is slender, elongated, and somewhat pointed when seen from the side (figs. $6, \mathrm{I}_{3}$ ), and is frequently overlaid by the tube nucleus (figs. 4,5 ). In this condition the pollen is shed. Hand pollination was successfully performed. Usually cross-pollination was effected, but it was demonstrated that pollen would produce abundant tubes on the stigma of the stylar branch under which it was located. Observation on the rate of growth of pollen during 7 hours after pollination was made, and their lengths measured with an ocular micrometer. Table I indicates results.

TABLE I

\begin{tabular}{|c|c|}
\hline Time after pollination & Length of tubes \\
\hline $\begin{array}{l}\text { I hour } \ldots \ldots \ldots \ldots \ldots \ldots \ldots \ldots \\
3 \text { hours } \ldots \ldots \ldots \ldots \ldots \ldots \ldots \ldots \ldots \\
5 \text { hours } \ldots \ldots \ldots \ldots \ldots \ldots \ldots \ldots \\
7 \text { hours } \ldots \ldots \ldots \ldots \ldots \ldots \ldots\end{array}$ & $\begin{array}{l}0 . \mathrm{I}-0.6 \mathrm{~mm} . \\
2-2.5 \\
4.5^{-5} \\
8-9.5\end{array}$ \\
\hline
\end{tabular}

The acceleration in the rate of growth, as indicated by these data, is interesting. In 9-10 hours tubes were observed at the base of the stylar branch. After 20 hours tubes were discovered 


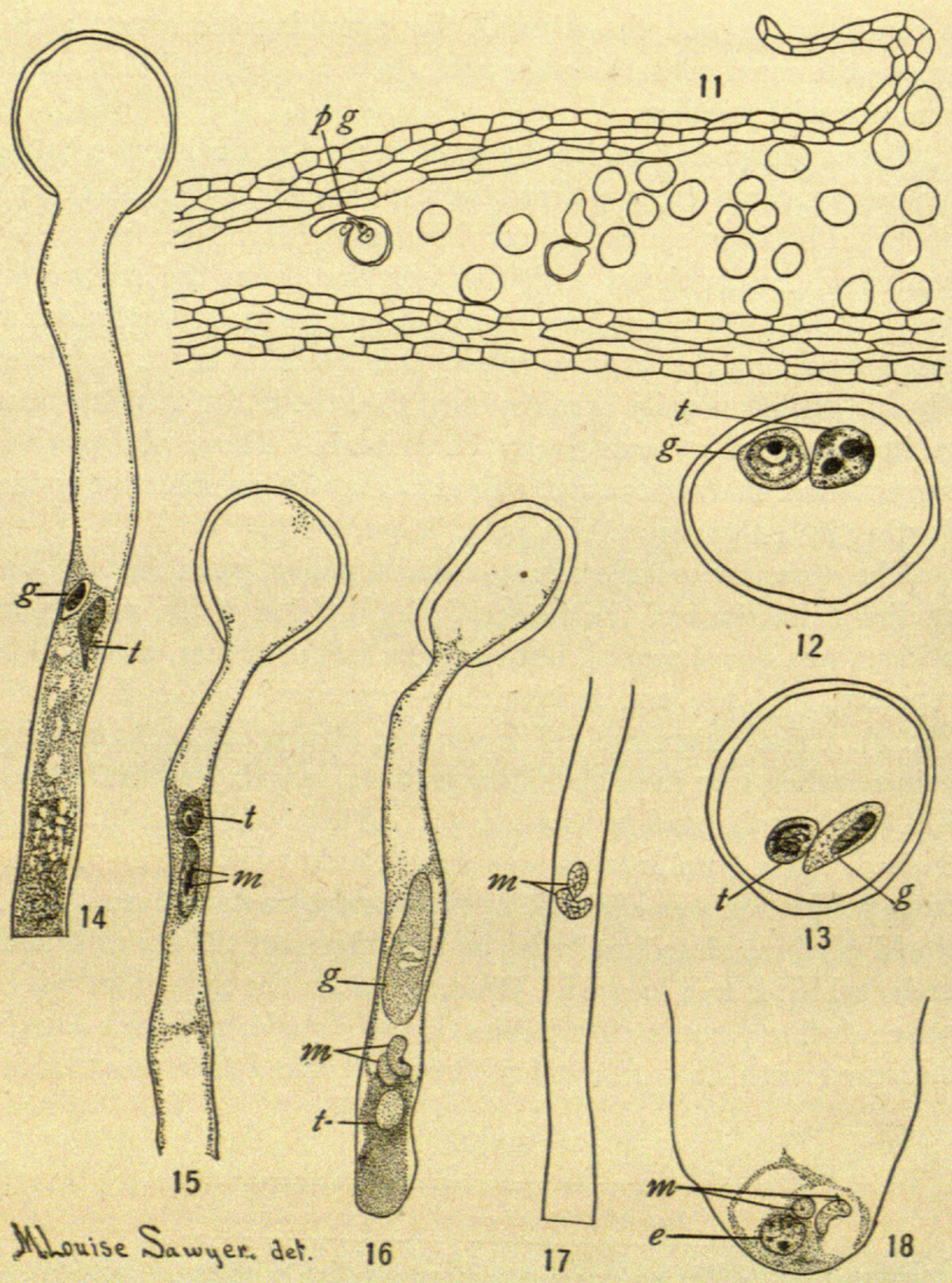

Figs. II-r8.-Abbreviations are as follows: $p g$, pollen grain; $t$, tube nucleus; $g$, generative cell; $m$, male cell; $e$, egg; fig. II, section of stigma with pollen grains, some of which are growing tubes, $X_{14}$; figs. $\mathrm{I}_{2}$ and $\mathrm{I}_{3}$, pollen grains in anther, showing appearance of tube nucleus and generative cell from different views, $X \mathrm{III}_{3}$; fig. I4, pollen tube with tube nucleus in act of passing generative cell, $X_{540}$; fig. $I_{5}$, pollen tube with generative cell containing 2 male nuclei preceding tube nucleus, $\times 540$; fig. 16 , pollen tube with tube nucleus and 2 male nuclei near tip, expanded cytoplasm of generative cell above showing cavities from which male nuclei escaped, $X_{540}$; fig. 17 , portion of a long pollen tube, showing 2 male nuclei free in tube, $X_{540}$; fig. 18 , end of embryo sac, with egg and 2 male nuclei, $\times_{540}$. 
within the ovary. The pollen tubes occasionally branch. This was observed both in tubes grown on the stigmas and in those grown on nutrient solutions (fig. 8). In the cell sap sugar solution some grains produced 2 tubes (fig. 9), indicating 2 germination spots.

Longitudinal sections of hand pollinated stigmas (fig. II) show pollen grains (fig. 5) which have essentially the characteristics of the grains in the dehiscing anthers, and among them grains which are producing pollen tubes. A tube (fig. 10) caught just as the tube nucleus and the generative cell were passing the tube distinctly shows the latter preceding, contrary to the order that is usually reported. In other cases the tube nucleus led the way from the grain into the pollen tube (fig. 7). The number of cases thus far observed at just this stage is not sufficiently large to warrant a statement as to which of these conditions is prevalent in Iris versicolor. Apparently it is usual for the tube nucleus to soon gain the leading position. One instance (fig. I4) of the tube nucleus in the act of passing the generative cell was observed. The peculiar elongated and pointed anterior end of the tube nucleus is very interesting and suggests a self-motile body.

The generative cell certainly usually passes into the tube before its nucleus divides to form the male nuclei, but occasional grains suggest the possibility that it sometimes divides in the grain. The division of the generative cell has not been observed, but in tubes dissected from the stigma, and in those grown in the culture media, the generative cell has frequently been seen apparently containing 2 nuclei (fig. ${ }^{5} \mathrm{~m}$ ). The contents, which microchemical tests show contain much starch, stain so heavily that it is difficult to differentiate the nuclei satisfactorily. The material seems to indicate a somewhat wide range in the position of the generative cell in the tube at the time division of its nucleus occurs.

A tube (fig. I6) but a fraction of a millimeter in length appeared to contain the tube nucleus, behind it the generative cell cytoplasm, and between them, free in the tube, the 2 male nuclei. In a group of dissected tubes which were about $\mathrm{I} 4 \mathrm{~mm}$. long, a tube contained free male nuclei (fig. 17 ) about halfway between the grain and the end of the pollen tube. At 79 hours after pollination such male nuclei were seen in the embryo sac (fig. I8). It is noticeable that 
in all of these cases no cytoplasm could be detected in association with the male nuclei, and also that in all views of these male nuclei one of them appears larger than the other, the larger one slightly vermiform. It remains to determine whether this apparent difference is real or whether in each case one of the nuclei is seen from the end. In the embryo sac section it seems probable that the smaller appearing one is the one likely to fertilize the egg.

\section{Summary}

I. The style of Iris versicolor is traversed by a longitudinal groove through which the pollen tube grows.

2. It is possible to remove pollen tubes from style and stigma and to grow pollen tubes in nutrient solutions.

3. Measurements indicate that there is an accelerated rate of growth of pollen tubes.

4. Pollen tubes may branch or a grain may produce two tubes.

5. The generative cell is an elongated, somewhat pointed cell, and may precede the tube nucleus from the tube.

6. Production of the male nuclei usually occurs after the generative cell has entered the tube.

7. The male nuclei may leave the generative cytoplasm, and were seen free in the tube.

8. The male nuclei were observed in the embryo sac 79 hours after pollination.

The writer is indebted to Professor H. D. Densmore of Beloit College for suggestions which led to the undertaking of this investigation. Acknowledgments are also due Professor JoHN M. Coulter and Dr. Charles J. Chamberlatn for helpful criticism during the progress of this work.

\section{Belott College}

Belort, Wrs. 


\section{$2 \mathrm{BHL}$ Biodiversity Heritage Library}

Sawyer, Marie Louise. 1917. "Pollen Tube and Spermatogenesis in Iris." Botanical gazette 64(2), 159-164. https://doi.org/10.1086/332101.

View This Item Online: https://www.biodiversitylibrary.org/item/109348

DOI: https://doi.org/10.1086/332101

Permalink: https://www.biodiversitylibrary.org/partpdf/223909

\section{Holding Institution}

Missouri Botanical Garden, Peter H. Raven Library

\section{Sponsored by}

Missouri Botanical Garden

\section{Copyright \& Reuse}

Copyright Status: Public domain. The BHL considers that this work is no longer under copyright protection.

This document was created from content at the Biodiversity Heritage Library, the world's largest open access digital library for biodiversity literature and archives. Visit BHL at https://www.biodiversitylibrary.org. 